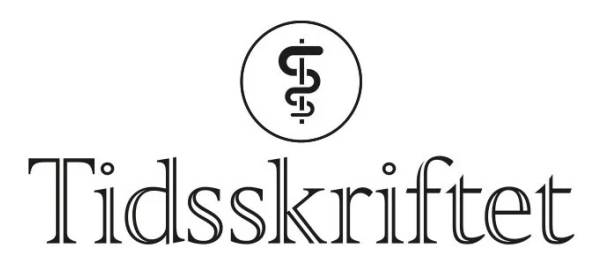

DEN NORSKE LEGEFORENING

\title{
Slik kan man få tilgang til legemidler uten vedtak i Beslutningsforum
}

KRONIKK

\section{ODD TERJE BRUSTUGUN}

otr@vestreviken.no

Odd Terje Brustugun er dr.med., spesialist i onkologi, overlege ved Onkologisk seksjon, Drammen sykehus, Vestre Viken, og professor ved Institutt for klinisk medisin, Universitetet i Oslo. Han er leder av Norsk lungekreftgruppe, leder av arbeidsgruppen som skriver nasjonalt handlingsprogram for lungekreft, medlem av LIS-onkologi spesialistgruppe og fast ekstern fagspesialist i Ekspertpanelet. Forfatteren har fylt ut ICMJE-skjemaet og oppgir følgende interessekonflikter: Han har mottatt forelesningshonorar fra en rekke legemiddelfirmaer samt forskningsstøtte til egen institusjon fra flere legemiddelfirmaer.

Det norske beslutningssystemet for innføring av nye legemidler er komplisert og tidkrevende. Hvordan kan man gå fram for å ta i bruk et legemiddel før en beslutning om innføring er fattet?

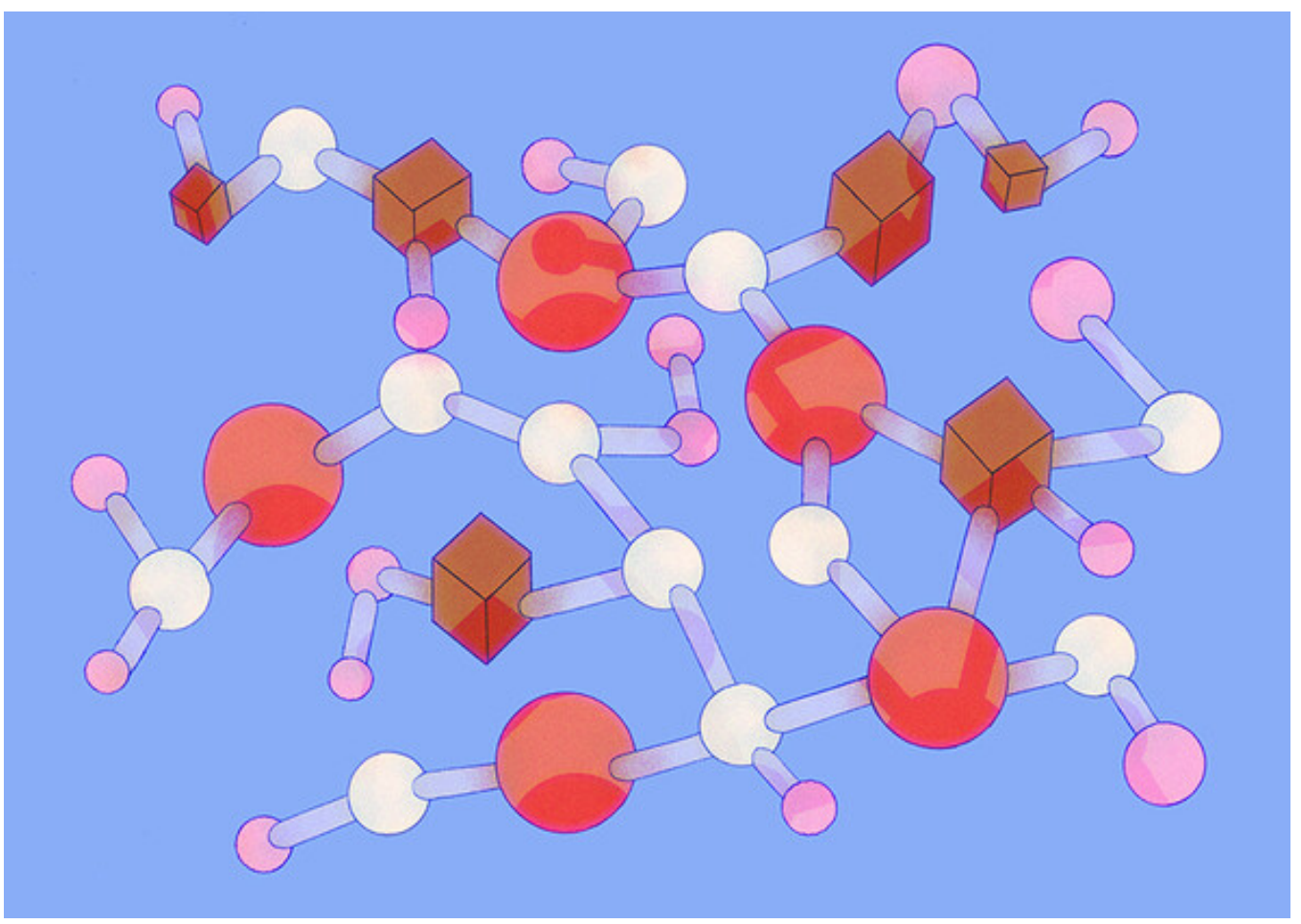


Illustrasjon: Steph Hope

Både enkeltsaker og den nylige gjennomførte evalueringen av Nye metoder-systemet ( 1 ) har aktualisert problemstillinger omkring pasienters tilgang til legemidler som ikke er generelt tilgjengelige i det norske offentlige helsevesenet. Har vi i Norge et for strengt og tregt system som gjør at pasienter mister vesentlig helsetilbud? Er systemet så komplisert at personer med ekstra ressurser har større mulighet for å få tilgang? Utfordres vårt «åpne

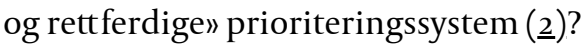

\section{«Er systemet så komplisert at personer med ekstra ressurser har større mulighet for å få tilgang?»}

I det følgende skal jeg med en klinikers perspektiv beskrive de ulike fasene i prosessen fram til et legemiddel blir allment tilgjengelig i spesialisthelsetjenesten. Jeg vil særlig omtale hvilke muligheter man har for å gi pasienter tilgang til et legemiddel som ikke har nådd den siste milepælen: et positivt vedtak i Beslutningsforum for nye metoder. All informasjon ligger på nettet, men det kan være vanskelig å orientere seg i dette terrenget. Temaet er særlig relevant for kreftsykdommer, men også for sykdommer innen bl.a. kardiologi (3) og nevrologi (4).

\section{Beslutninger på to nivåer}

Det er to viktige beslutninger i prosessen fram til et legemiddel kan tas i rutinemessig bruk i Norge. Den ene er markedsføringstillatelse. Den andre er positivt vedtak i

Beslutningsforum for nye metoder. Begge omtales ofte som godkjenninger, men formelt sett er det markedsføringstillatelsen som er den regulatoriske godkjenningen, mens Beslutningsforum vedtar om legemidlet skal innføres i spesialisthelsetjenesten for en bestemt indikasjon.

Markedsføringstillatelse gis i Europa av EU-organet Det europeiske legemiddelbyrået (EMA). Slik EMA-godkjennelse gis når det vurderes at et medikament har en medisinsk nytte som overstiger medisinsk risiko, uten at kostnader tas hensyn til. Etter at Det europeiske legemiddelbyrået har gitt markedsføringstillatelse, vil EØS-landene gi nasjonal markedsføringstillatelse i løpet av zo dager.

At et legemiddel har markedsføringstillatelse, er imidlertid ikke det samme som at legemidlet kan tas i generell bruk i vårt offentlige helsevesen. Det er ofte en temmelig lang og innfløkt prosess før et legemiddel kan gis rutinemessig til norske pasienter.

Det er først når Beslutningsforum har vedtatt at et legemiddel kan innføres for en gitt indikasjon, og Divisjon legemidler i Sykehusinnkjøp har satt legemidlet øverst på sin prioriteringsliste, at legen kan forskrive legemidlet og pasienten kan ta det rutinemessig $i$ bruk. Men det finnes også måter et legemiddel kan tilbys pasienter selv om det ikke har gått igjennom hele denne prosessen.

\section{Kliniske studier}

Studier gir tilgang til legemidler lenge før de er allment tilgjengelige. Legemidlene blir dessuten gratis for helsevesenet når studiene gjøres på oppdrag eller i samarbeid med legemiddelindustrien, noe som gjelder i de fleste tilfellene. Både studiedesign og geografisk plassering er dermed styrt av kommersielle interesser. Inklusjons- og eksklusjonskriterier kan være stramme, slik at bare et utvalg av relevante pasienter får tilbud om behandling. 
Forskerinitierte studier med eller uten industristøtte kan være mer krevende å få etablert, men her vil både studiedesign og pasientutvalg være uavhengig av kommersielle interesser. Man kan få mulighet til å tilby et relativt stort antall pasienter å bli inkludert $\mathrm{i}$ studien. I Norge har vi mange eksempler på slike prosjekter som har gitt og gir pasienter tilgang til potensielt effektive legemidler som ikke er tilgjengelige på andre måter. Det er et uttalt mål fra helsemyndighetene å øke antall pasienter som inkluderes i kliniske studier. Likevel er antallet norske pasienter i kliniske studier dessverre gått ned de senere årene (5).

\section{Behandling med legemiddel uten godkjenning}

I fasen fra pasientinklusjon i kliniske studier er avsluttet og fram til legemidlet får markedsføringstillatelse, vil legemidlet ikke være tilgjengelig, verken i studier eller for vanlig forskrivning. I denne perioden vil noen legemidler tilbys i et program for tidlig tilgang (early access program). Legen kan da få tilgang til medikamentet etter spesiell søknad, både til det aktuelle legemiddelfirmaet og til legemiddelmyndighetene. I tillegg må det inngås en avtale mellom firmaet og et regionalt helseforetak (RHF). Firmaene har ikke anledning til å reklamere for denne type tilgjengelighet, så det kan være krevende å ha oversikt over hvilke muligheter som finnes. På nettsidene til Nye metoder finnes en til enhver tid oppdatert liste over nye legemidler som ennå ikke har fått markedsføringstillatelse (므).

Det er ikke gitt at legemidler på denne listen tilbys fra legemiddelfirmaet. Man må sende en forespørsel til firmaet i hvert enkelt tilfelle. Dersom legemiddelfirmaet tilbyr det $\emptyset$ nskede legemidlet, må det inngås en nasjonal standardavtale mellom firmaet og det regionale helseforetaket. Det er tilstrekkelig at en slik nasjonal avtale er inngått én gang per legemiddel. Dersom én pasient har fått dette legemidlet på aktuell indikasjon, trenger man ikke inngå en ny avtale for etterfølgende pasienter. En liste over legemidler hvor det allerede er inngått avtale, ligger på nettsidene til Nye metoder (므).

\section{«Prosessen med å få godkjenningsfritak for enkeltpasienter går i de aller fleste tilfeller smidig og raskt»}

Høsten 2021 ble det innført to ulike avtaler, en for legemidler med «kort forventet behandlingsvarighet» (7.) og en for andre legemidler (므). Kreftlegemidler av typen persontilpasset medisin vil typisk være aktuelle for den første avtalevarianten. Standardavtalen inneholder bestemmelser om at legemiddelfirmaet forplikter seg å tilby legemidlet så lenge pasienten har klinisk nytte av det. Alle pasienter som oppfyller kriteriene for behandling, skal tilbys legemidlet så lenge preparatet ikke har fått markedsføringstillatelse. Legemidlet skal tilbys gratis til pasienter med nytte fram til seks måneder etter markedsføringstillatelse, deretter skal sykehuset betale $10 \%$ av maksimalpris fram til et eventuelt positivt vedtak i Beslutningsforum. Fra da av vil framforhandlet pris gjelde.

Den generelle standardavtalen som gjelder for medikamenter uten «kort forventet behandlingsvarighet», er i hovedsak lik den beskrevne, men krever at legemidlet skal tilbys gratis så lenge pasienten har nytte av det og fram til et eventuelt positivt vedtak i Beslutningsforum.

Signering av standardavtalen må altså gjøres før første pasient starter behandlingen. Globale deler av firmaet kan bli involvert, og det kan være juridiske problemstillinger som må avklares. Betingelsene i avtaleteksten er ufravikelige. Denne prosessen kan ta noe tid. 
I tillegg til signert avtale må enten legemidlet inngå i et program for bruk av legemidler under utprøvning (såkalt compassionate use) godkjent av Legemiddelverket (SLV), eller legen må søke om godkjenningsfritak for enkeltpasienter (også kalt compassionate use, named patient). Erfaringen er at svært få legemiddelfirma etablerer slike programmer i Norge. Legemiddelverket opplyser om at det er tre slike programmer for tiden. Prosessen med å få godkjenningsfritak for enkeltpasienter går imidlertid i de aller fleste tilfeller smidig og raskt. Legemiddelverkets standardblankett for godkjenningsfritak benyttes og sendes Legemiddelverket via sykehusapoteket. Lokalt apotek bør involveres tidlig i prosessen, fordi det kan være behov for å avklare importordninger etc. Apotekets kostnader med lagring, tilvirkning og annen håndtering må dekkes av den kliniske avdelingen.

Når formalitetene er i orden, kan legemidlet bestilles, ofte via en nettportal hvor man registrerer klinisk informasjon og opplysninger om mottaker. Erfaringsmessig går det da kun få dager til legemidlet er mottatt og pasienten kan starte behandling. Det kan variere hvor lenge et legemiddel er tilgjengelig via et program for tidlig tilgang, men når legemidlet får markedsføringstillatelse, stenges denne muligheten. Legemiddelfirmaet kan også velge å stoppe inklusjon av nye pasienter før markedsføringstillatelsen er gitt, men ved inngåelse av standardavtalen kreves et minimum av tre måneders inklusjonstid $\mathrm{i}$ etterkant.

\section{Unntaksordninger}

Når et legemiddel innvilges markedsføringstillatelse, vil det som regel allerede være inkludert i Nye metoders metodeutredningssystem. Det er Bestillerforum, som består av de fire helseregionenes fagdirektører i tillegg til representanter fra Helsedirektoratet, som avgjør om et legemiddel skal gjennomgå metodevurdering. Så lenge et legemiddel med markedsføringstillatelse er til slik vurdering, skal det i prinsippet ikke tas i bruk i spesialisthelsetjenesten.

Denne fasen fram til det fattes vedtak i Beslutningsforum kan være lang (figur 1) (9.). Nye metoder oppgir en mediantid på ca. ett år fra markedsføringstillatelse til vedtak i Beslutningsforum (10 $)$. I denne fasen vurderer Legemiddelverket legemidlets kostnadnytte-forhold og relative effekt. Parallelt gjøres prisforhandlinger med produsent. Dette kan tidvis ta lang tid, og priskonklusjonen er hemmelig (1ㅡ).

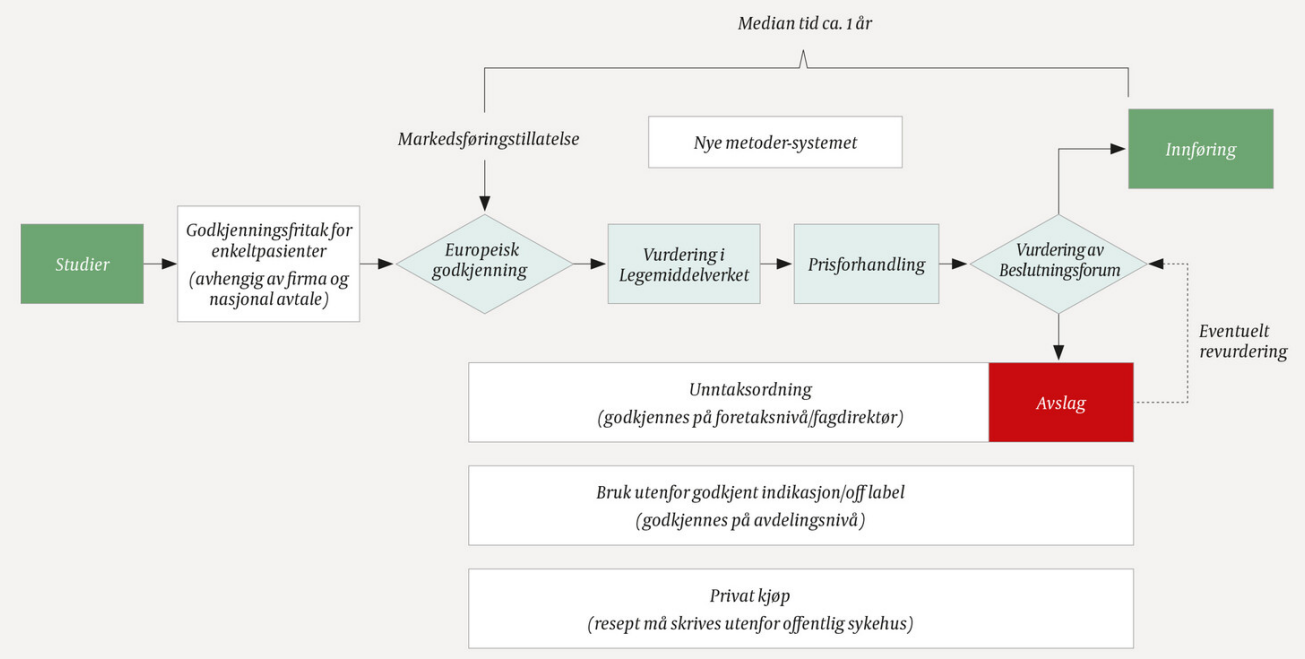

Figur 1 Skjematisk oversikt over de ulike fasene fra kliniske studier til et legemiddel kan tas i alminnelig bruk, samt mulighetene for tilgang uten positivt vedtak i Beslutningsforum. Modifisert fra figur laget av Norsk lungekreftgruppe (9). 
Så lenge et preparat er til vurdering kan man søke om unntaksbruk. I denne fasen er legemidlet gjerne godt kjent både av leger og legfolk, og det kan være et press på å få ta det $\mathrm{i}$ bruk. Det er to ulike unntaksordninger: gruppeunntak, der en forhåndsdefinert pasientkategori kan starte å bruke et medikament før det har fått endelig positivt vedtak i Beslutningsforum, og enkeltpasientunntak.

Gruppeunntak gis av det interregionale fagdirektørmøtet, dvs. Bestillerforum unntatt representantene fra Helsedirektoratet, etter at et fagmiljø har søkt «i linjen» i et helseforetak. Det har vært få eksempler på slike unntak. For tiden er det to pågående gruppeunntaksordninger, henholdsvis for kolorektalkreft og prostatakreft med spesifikke molekylære karakteristika (프). Interessant nok var karpaltunnelkirurgi også i en periode håndtert som et gruppeunntak. Slike unntak vil gjelde for alle pasienter som tilhører en viss kategori, har nasjonalt omfang, og virketiden er inntil saken har vært til vedtak i Beslutningsforum.

\section{«Det har vist seg at tolkningen av disse unntaksbestemmelsene har variert mellom foretakene»}

Unntaksvis kan også enkeltpasienter innvilges bruk av et legemiddel som ikke ennå har oppnådd positivt vedtak i Beslutningsforum. Kriteriene for dette er at det er grunnlag for å tro at nytten for pasienten «vil være vesentlig større enn for gruppen som helhet» (13). Legemidlet må også ha markedsføringstillatelse for aktuell indikasjon. Søknad om slik unntaksbruk kan behandlende lege sende til fagdirektør i eget foretak, som tar beslutningen.

Det har vist seg at tolkningen av disse unntaksbestemmelsene har variert mellom foretakene, og innvilgede unntak synes generelt å være få. For eksempel kan det være noe uklart hva som menes med "gruppen som helhet» og det er ofte ikke opplagt hvem som vil ha spesielt god nytte. Ung alder i seg selv synes ikke å være relevant. For å forsøke å kalibrere vurderingene skal en kopi av unntaksbeslutningene sendes til regional fagdirektør. Unntaksordningene er ganske inngående drøftet i evalueringsrapporten av Nye metoder (s. 188-191), og det konkluderes bl.a. med at man er «usikre på om ordningen fungerer tilfredsstillende» (1).

Dersom Beslutningsforum vedtar at preparatet ikke skal tas i bruk, lukkes også muligheten for unntaksbruk. Denne muligheten gjelder kun preparater som er til vurdering. Bestillerforum kan restarte en vurderingsprosess dersom viktige forutsetninger endres, for eksempel dersom pristilbudet blir senket, eller det kommer nye effektdata som reduserer usikkerheten knyttet til nytteverdien.

\section{Bruk utenfor godkjent indikasjon}

Bruk av legemidler utenfor godkjent indikasjon omtales gjerne som off label-bruk (13). Dette kan være aktuelt for alle preparater med markedsføringstillatelse, i prinsippet uavhengig av om det har positivt vedtak fra Beslutningsforum.

Slik bruk besluttes og finansieres på avdelingsnivå. Nye legemidler som ikke har vært gjennom en prisforhandling, kan ha en svært høy kostnad. Det vil da være fornuftig av behandlende lege å drøfte slik bruk med sin leder før igangsetting.

\section{Privat innkjøp}

Preparater med markedsføringstillatelse vil også kunne kjøpes med private midler eller egen helseforsikring. Forskrivning må da gjøres av en privat aktør. Offentlige sykehus vil ikke uten videre ta ansvar for bildeevaluering etc. utover det som ville være aktuelt å gjøre 
som standardoppfølging uten den private behandlingen. Akutte bivirkninger må selvsagt tas hånd om av offentlige sykehus på vanlig måte.

Det har vært eksempler på at pasienter som har startet privat og oppnådd god effekt, har fått videre behandling ved offentlig sykehus. Disse sakene har vært vanskelige, og det diskuteres fortsatt hvordan man best skal løse disse problemstillingene. Det ligger utenfor denne kronikken å gå nærmere inn på disse sakene.

\section{Ekspertpanelet}

For pasienter med langtkommen sykdom kan en henvendelse til Ekspertpanelet være aktuelt (14.). Dette organet kan gi bistand til å vurdere om det finnes kliniske studier eller andre relevante behandlingstilbud utover det som ansees å være standardbehandling. Ekspertpanelet har kun en rådgivende funksjon uten beslutningsmyndighet. Deres råd kan tas til følge, eller man kan i samråd med pasient og eget foretak vurdere andre alternativer, inkludert det å ikke gi ytterligere behandling. Også denne ordningen er under evaluering (15).

\section{LITTERATUR}

1. Evaluering av systemet for Nye metoder i spesialisthelsetjenesten. Proba samfunnsanalyse rapport 2021-16. Oslo: Helse- og omsorgsdepartementet, 2021.

https://www.regjeringen.no/contentassets/o9874ao573eb480384061da473458ed1/rapport-evalueringnye-metoder-2021115-ferdig.pdf Lest 5.1.2022.

2. NOU 2014:12. Åpent og rettferdig - prioriteringer i helsetjenesten. https://www.regjeringen.no/contentassets/16ao834c9c3e43fab452ae1b6d8cd3f6/no/pdfs/nou201420140 o120oodddpdfs.pdf Lest 5.1.2022.

3. Sykehuset gir ham medisinen. Men siste ord er ikke sagt. Aftenposten 8.12.2021. https://www.aftenposten.no/norge/i/47VmRg/sykehuset-gir-ham-medisinen-men-siste-ord-er-ikkesagt Lest 5.1.2022

4. MS-medisin på møteagendaen etter at flere sykehus trosset vedtak i Beslutningsforum, Dagens medisin 5.8.2021. https://www.dagensmedisin.no/artikler/2021/o8/05/ms-medisin-pa-moteagendaenetter-at-flere-sykehus-trosset-vedtak-i-beslutningsforum/ Lest 5.1.2022

5. Nasjonal handlingsplan for kliniske studier 2021-2025. Oslo: Helse- og omsorgsdepartementet, 2021. https://www.regjeringen.no/contentassets/c3dcdb95b7d741319c62642865afadad/i1206b_kliniske_studier_uu.pdf Lest 5.1.2022.

6. Retningslinje for bruk av nye legemidler før markedsføringstillatelse (MT), 2021. https://nyemetoder.no/om-systemet/retningslinje-for-bruk-av-nye-legemidler-formarkedsforingstillatelse-mt Lest 5.1.2022.

7. Tillegg til Retningslinjer for bruk av nye legemidler før markedsføringstillatelse. Vilkår for legemidler med kort forventet behandlingsvarighet, 2021.

https://nyemetoder.no/Documents/Om\%2osystemet/Tillegg\%2otil\%2oRetningslinjer\%2ofor\%2obruk\%2 oav\%2onye\%2olegemidler\%2of\%c3\%b8r\%2oMT.pdf Lest 5.1.2022

8. Retningslinjer for bruk av nye legemidler, 2018.

https://nyemetoder.no/Documents/Om\%20systemet/2017-02-12\%2orapport-

retningslinjer\%2olegemidler\%2of\%c3\%b8r\%20MT\%20\%28002\%29.pdf Lest 5.1.2022

9. Norsk lungekreftgruppe. Lungekreftpreparater uten positivt Beslutningsforumvedtak.

http://nlcg.no/ikke-tilgjengelige-lungekreftpreparater/ Lest 5.1.2022

10. Tidsbruk 2020 - Legemidler. Nye Metoder, 2021.

https://nyemetoder.no/Documents/Om\%2osystemet/Tidslinjer\%2oNye\%2ometoder_legemidler_2020. pdf Lest 5.1.2022

11. Forholdet mellom Nye Metoder og anskaffelser. Prisforhandling. https://nyemetoder.no/omsystemet/forholdet-mellom-nye-metoder-og-anskaffelser Lest 5.1.2022.

12. Unntaksordning. Nye Metoder. Om systemet. https://nyemetoder.no/omsystemet/unntaksordning Lest 5.1.2022. 
13. Raknes G. Utenfor etiketten? Tidsskr Nor Legeforen 2018; 138. doi:10.4045/tidsskr.18.0522. [PubMed][CrossRef]

14. Ekspertpanelet. Nasjonalt organ for rådgivning ved alvorlig livsforkortende sykdom. https://helse-bergen.no/ekspertpanelet Lest 5.1.2022.

15. Protokoll frå føretaksmøte. Helse Vest RHF 20. April 2021. Stortingsvedtak m.m. Helse Vest: Helseog omsorgsdepartementet. Evaluering av ekspertpanelet for spesialisthelsetenesta, 2021. https://www.regjeringen.no/contentassets/caada2c3894a459391265fe767966439/protokollforetaksmote-i-helse-vest-rhf-20.-april-2021.pdf Lest 5.1.2022

Publisert: 27. januar 2022. Tidsskr Nor Legeforen. DOI: 10.4045/tidsskr.21.0886 Mottatt 17.12.2021, godkjent 20.12.2021.

(C) Tidsskrift for Den norske legeforening 2023. Lastet ned fra tidsskriftet.no 26. april 2023. 